\title{
"The impact of the board process on board and corporate performance: the case of Slovakia"
}

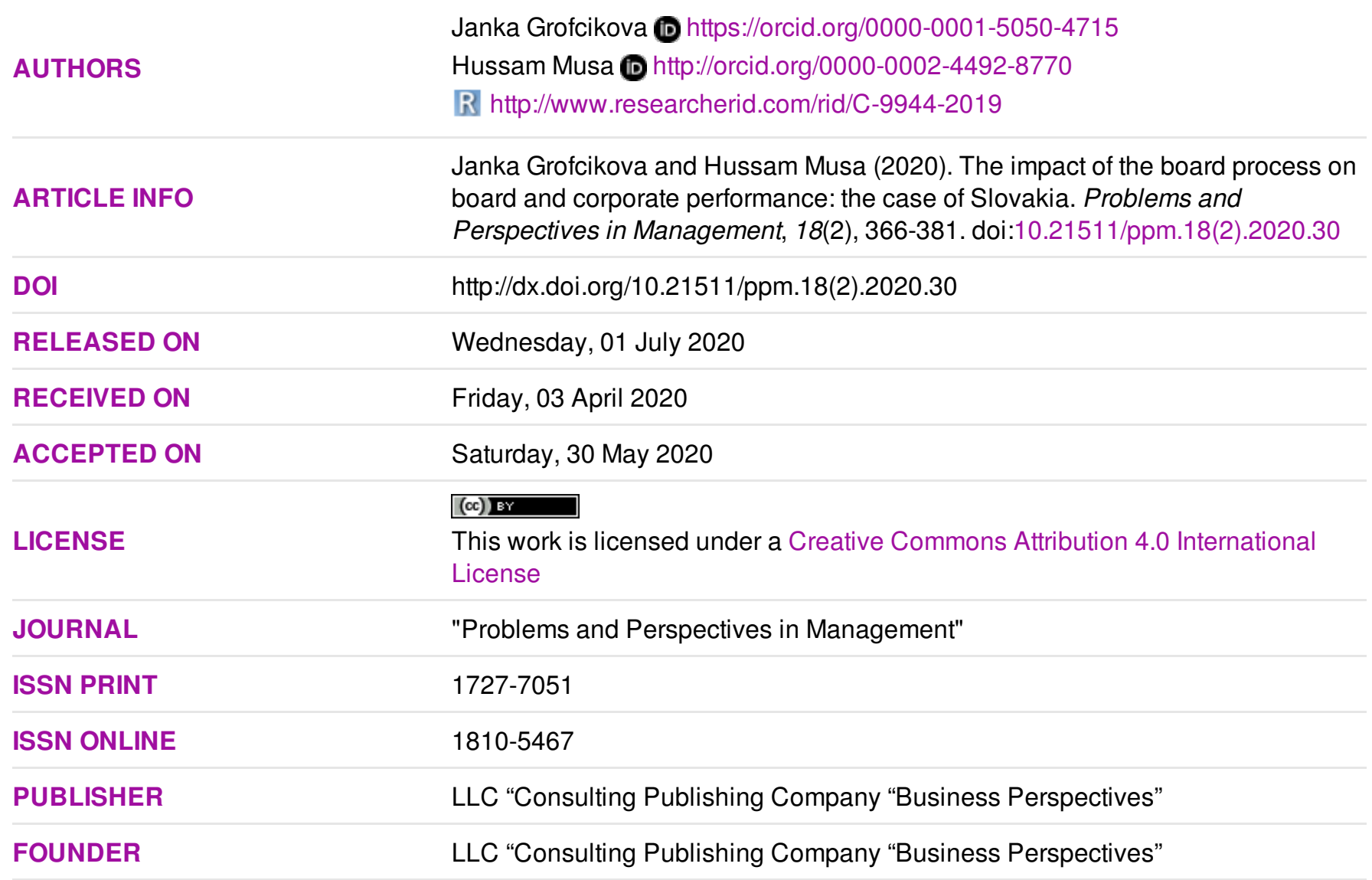

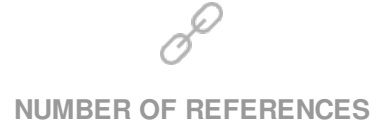

54

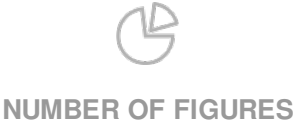

0
E=

NUMBER OF TABLES

9

(C) The author(s) 2021. This publication is an open access article. 


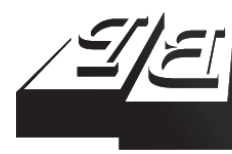

\section{BUSINESS PERSPECTIVES}

(O)

LLC "CPC "Business Perspectives" Hryhorii Skovoroda lane, 10 Sumy, 40022, Ukraine www.businessperspectives.org

Received on: $3^{\text {rd }}$ of April, 2020 Accepted on: $30^{\text {th }}$ of May, 2020 Published on: $1^{\text {st }}$ of July, 2020

(c) Janka Grofcikova,

Hussam Musa, 2020

Janka Grofcikova, Assistant Professor, Department of Finance and Accounting, Faculty of Economics, Matej Bel University in Banská Bystrica, Slovak Republic.

Hussam Musa, Professor, Department of Finance and Accounting, Faculty of Economics, Matej Bel University in Banská Bystrica, Slovak Republic. (Corresponding author)

\title{
THE IMPACT OF THE BOARD PROCESS ON BOARD AND CORPORATE PERFORMANCE: THE CASE OF SLOVAKIA
}

\begin{abstract}
Nowadays a great deal of attention is paid to corporate governance (CG). Frequent takeovers of ownership rights by management bodies led to a need for business owners to establish clear rules for business management and compliance monitoring. The aim of this paper is to examine the relationship between selected characteristics of the governance process and the ability of governing bodies to perform their core tasks, as well as to model and predict the impact of the selected characteristics of the governance process on the company's financial performance, measured by the year-on-year change in return on equity. The respondent sample consists of members of randomly selected top management entities with their headquarters in Slovakia. A total of 132 subjects participated and answered questions in the survey, 54\% of which were joint stock companies, $36 \%$ were limited liability companies and $10 \%$ were respondents from cooperatives. Data were personally collected by a questionnaire survey conducted during 2019. To verify the assumptions and success of the formulated model, correlation analysis, binary logistic regression and other relevant tests were used. The results show that each of the examined board process attributes significantly affects at least one board performance attribute. All significant correlations have a positive value. Independent variables in the ROE regression model increased the estimation rate of ROE change from $54.5 \%$ to $93.9 \%$. The model is applicable in the CG practice and allows the prediction of changes in ROE with respect to ongoing governance processes.
\end{abstract}

\section{Keywords}

\section{JEL Classification $\quad$ G22, G34, M14}

\section{INTRODUCTION}

A few decades ago, the public was almost unaware of the concept of corporate governance. However, scandals and financial crises of recent years have made this term quite commonly used not only in the business environment, but also amongst the public. This concept, which used to be mostly the subject of closed-door discussions, has continuously turned into a public concern. Since the concept concerns the interests of several groups involved and is still considered to be a relatively new phenomenon, it is difficult to define it explicitly (Ararat \& Ugur, 2003). Beside this, as the OECD Corporate Governance Report (OECD, 2015) indicates, there is no unique model of good corporate governance. Apparently, the basic principles of good corporate governance include support and provision of transparent and efficient markets, protection and facilitation of exercising the shareholder rights, guarantee of fair treatment of all shareholders, as well as a guarantee of timely and accurate disclosure of all materials that are related to the company.

Several institutions worldwide also pay attention to corporate governance issues. Among the most important is the Organisation for 
Economic Co-operation and Development (OECD). In 1999, this organization developed the first set of corporate governance principles, which was revised and amended in 2004 and 2015. The current valid version was developed in cooperation with the OECD Governance Committee and the states of G20. This document has six separate chapters:

(I) Ensuring the basis for an effective CG framework;

(II) The rights and equitable treatment of shareholders and key ownership functions;

(III) Institutional investors, stock markets, and other intermediaries;

(IV) The role of stakeholders in CG;

(V) Disclosure and transparency; and

(VI) The responsibilities of the board.

Each of the chapters contains a list of supporting sub-principles, supplemented by explanatory notes (Grofcikova \& Izakova, 2018; OECD, 2015). Corporate governance has become an international issue due to globalization of businesses (Musa, Rech, \& Musova, 2019).

The study explores the relationship between selected characteristics of the management process and the ability of management authorities to fulfill their core tasks. The effect of these characteristics on the company's financial performance is modelled and predicted.

\section{LITERATURE REVIEW}

Several authors have tried to define the concept of corporate governance. Cadbury (1992) defined it as a system or process by which companies are managed and controlled. In this regard, corporate governance, in accordance with the theory of Gillan and Starks (1998), consists of the law, rules and factors that make it possible to control the activities of a company, as well as relationships between various persons involved in the system, such as management, board, shareholders, and other stakeholders. Jensen (1993) divides corporate governance into two parts - the internal and the external one. The internal corporate governance system consists of the management and the board. On the other hand, the external corporate governance system involves external funding providers, shareholders and corporate debt holders. With regard to this concept, Shleifer and Vishny (1997), Jensen and Meckling (1976), and Gillan (2006) assume that the key corporate governance mechanism is to get a return on investments provided by funders; however, some fundamental problems need to be solved to achieve this goal. Effective and good corporate governance may thus contribute to sustainable economic development through higher performance of companies and better access to external capital (Akinleye, Olarewaju, \& Fajuyagbe 2019; Grofcikova, 2016;
Kliestik, Valaskova, Lazaroiu, Kovacova, \& Vrbka, 2020). On the one hand, implementation and maintenance of good governance facilitates decision-making, and, at the same time, it may enhance strategy, performance, compliance and accountability. On the other hand, it concerns the continuous monitoring and evaluation. Thus, effective corporate governance helps a company achieve its goals and expected results and meet its commitments through reliable strategic and business planning, risk management, financial management and reporting, human resources planning and control, and a compliance and accountability system.

\subsection{Measuring the Board of Directors' performance and its impact on corporate performance}

The literature on research related to performance of the Board of Directors is based on two basic methodological approaches - direct and process approaches.

The majority of conducted studies apply the direct approach, which enables examination of a direct relationship between the board of directors and corporate performance. This concept is based on the assumptions that key attributes of the Board of Directors, such as size, structure, composition, 
and others, have a direct impact on company performance (Daily \& Dalton, 1994; Dalton, Daily, Ellstrand, \& Johnson, 1998; Freire, 2019). This approach is based on the phenomenon of compliance, and it is reinforced by the difficulty in measuring or directly observing the board process. It assumes that the behavior of the Board of Directors can be successfully predicted only on the basis of its demographic characteristics (Lawrence, 1997; Levrau \& Van Den Berghe, 2007; Priem, Lyon, \& Dess, 1999; Judge \& Zeithaml, 1992). The direct approach is criticized for two reasons. The first reason concerns the fact that governance processes are implicitly regarded as a black box, while this approach ignores their potential impact on the ability of administrations to perform their duties (Pearce \& Zahra, 1992; Pettigrew, 1992). The second reason indicates that these studies are often inadequate, ambiguous and unconvincing (Kiel and Nicholson, 2003). Some studies confirm a positive (Pearce \& Zahra, 1992; Daily \& Dalton, 1993), and other confirm a negative relationship between the Board and the company's performance (Conyon \& Peck, 1998; Yermack, 1996).

The process approach enables better understanding of the role of the Board of Directors in the company. This approach is based on the assumption that the performance of the Board of Directors is a function of its inputs and processes. Therefore, the right processes must be in place to transform these inputs into desired performance results. According to the procedural approach, research focuses on collecting and analyzing data on Board processes and Board activities, instead of direct interconnection between the selected Board characteristics and the company performance (Dalton, Daily, Ellstrand, \& Johnson, 1998; Maassen, 1999). Recent studies favor the process approach due to several reasons. The relationship between the attributes of the Board of Directors and the company performance is complex and cannot be partially quantified. The beliefs and behaviors of the Board of Directors' members cannot be reliably derived from selected demographic characteristics. Recent research findings indicate that these are the activities of the authorities themselves, which should be addressed, as well as the way how the boards operate and to what extent their activities affect the company performance (Lawrence, 1997; Melone, 1994; Amason \& Sapienza, 1997; Ong \& Wan, 2008).
The effectiveness of corporate governance is perceived as a basic requirement for achieving a satisfactory financial performance of a company on the assumption that effective corporate governance will also have a positive impact on its performance. Studies have identified at least three critical roles of the Board, namely monitoring and control, service and strategic roles (e.g., Gopinath, Siciliano, \& Murray, 1994; Hung, 1998; Johnson, Daily, \& Ellstrand, 1996; Maassen, 1999). The Board shall be deemed to be executive under the condition that it is able to perform its tasks. Corporate governance studies focus mainly on the monitoring and control roles of the Board of Directors, due to an increase in legislative regulation of the governing bodies' rights and duties, the occurrence of plenty of corporate scandals and the popularity of agency theory (Jensen \& Meckling, 1976; Jackling \& Johl, 2009). The service role of the Board of Directors is based on

1) the resource-based theory, according to which the Board of Directors, through its professional and personal qualifications, supports the management of a company and provides it with necessary advice;

2) the resource dependency theory, which is based on a premise that businesses need external funding to generate added value and output; and

3) the stakeholder theory, according to which the Board of Directors should be composed of members representing various stakeholders so that they can legitimize and protect their interests, identify key stakeholders and manage their potential conflicting interests, and thereby enhance an increase the social performance of a company (e.g., Boeker \& Goodstein, 1991; Boyd, 1990; Daily \& Dalton, 2003).

There are two views of the strategic role of the Board of Directors in a company. The first group of authors states the low involvement of the Board of Directors in strategic functions, as this role is fulfilled by management in the company. The other view highlights the independence of the Board of Directors and its contribution to formulating corporate strategies and directing its management 
towards achieving the company's mission and goals (Levrau \& Van Den Berghe, 2007).

The process aspects of the Board of Directors' activities relate to decision-making activities and the behavior of its members, which may affect the Board's ability to perform its tasks.

\subsection{Legislative regulation of the board competence of companies and cooperatives in Slovakia}

The basic legal norm that regulates the establishment, extinction and operation of companies and cooperatives in the Slovak Republic is The Commercial Code No. 513/1991 Coll. as amended. Section 56 par. 1 of the Code defines a company as a legal entity established for the purpose of doing business. The term company is related to a public company, limited partnership, limited liability company, joint stock company, and simple stock company. Sections 221 and 222 define a cooperative as a legal entity established for the purpose of doing business or meeting the needs of its members. Bodies entrusted with a certain range of competences and duties establish a limited liability company, a joint stock company, a simple company for shares and a cooperative in accordance with the Code and bylaws. The following part of the paper will review the current legislation in the area of corporate governance in Slovakia.

The specifics of the formation and management of a limited liability company are regulated by the Commercial Code in paragraphs 105-153. The minimum share capital is 5,000 Euros. The Memorandum of Association shall, inter alia, pursuant to Section 110, contain the names of the company's executives and members of the Supervisory Board, if established by the company. The bodies of a limited liability company are defined in the Commercial Code in paragraphs 125-140. The General Meeting of shareholders is the company's supreme body. Within the scope of its activity, the company is responsible for approving the financial statements, deciding on profit distribution and paying losses, approving the Articles of Association and their changes, as well as deciding on changes in the Memorandum, changes in share capital, or the sale, appointment or dismissal of directors and supervisory board members. The General Meeting may also reserve decisions on matters that are otherwise within the competence of other company bodies. Unless the Memorandum of Association or the company's bylaws stipulate otherwise, the General Meeting is convened by the company's executives at least once a year. The subject of the General Meeting (pursuant to Section 193 of the Commercial Code) is the information on the principal intentions of the company's management for the future, the information on the anticipated development of the company's assets, finances and revenues, and these are confronted with the results of the previous period. This information is submitted for negotiation by the company executives. Managers are also obliged to inform the Supervisory Board of all facts that may significantly affect the business activity of the company, the state of its assets and especially its liquidity. Minutes shall be made of the progress and outcome of the General Meeting. Executives are the statutory body of a limited liability company. The executive of the company can only be a natural person/an individual. The executives are appointed by the General Meeting from among the members or other individuals. Executives are obliged, in accordance with Section 135 , to ensure proper keeping of the requisite records and accounting, to keep the list of partners and to inform the partners about company matters. They submit the separate financial statements and the proposal for distribution of profit or compensation of loss, if required by the Accounting Act, also the annual report of the company to the General Meeting for approval. The annual report is compulsorily prepared by an accounting unit, which, in accordance with Section 19 of Act No. 431/2002 Coll. on Accounting, verifies its financial statements by auditors. The content of the annual report is determined by Section 20 of the Act on Accounting. According to Section 135a of the Commercial Code, executives are obliged to exercise their powers with professional care and in accordance with the interests of the company and all its stakeholders. In particular, they are obliged to obtain and take into account all available information regarding the subject matter of the decision, to maintain secrecy, and in the exercise of their sovereignty they must not give priority to their interests or the interests of only some partners 
or third parties over the company's interests. The activities of the executives are supervised by the Supervisory Board, if it is established in the company by a Memorandum of Association. In addition, this body controls business and accounting books and other documents, examines the financial statements and the proposal for distribution of profit, or compensation of loss, and it shall report its findings to the General Meeting at least once a year. The members of the Supervisory Board shall attend the General Meeting and shall be given the floor whenever they request.

The specifics of the establishment and management of a joint stock company are regulated by the Commercial Code in Sections 154 to 220. The minimum share capital of a joint stock company is 25,000 Euros. General Meeting is the supreme body of a joint-stock company. The General Meeting convenes the Board of Directors at least once a year. According to Section 180 of the Commercial Code, a shareholder is entitled to attend and vote in the general meeting, to request information and explanations concerning the matters of the company or persons controlled by the company related to the subject of the meeting, and to make proposals thereon. The Board of Directors of a joint stock company is obliged to provide each shareholder with full and truthful information and explanations related to the subject of the General Meeting. Pursuant to Section 187 of the Commercial Code, the powers of the General Meeting include, in particular, amendment of the Articles of Association, decision to change the registered capital, election and dismissal of members of the Board of Directors, Supervisory Board and other bodies designated by the Articles of Association, approval of financial statements and decision on distribution of profit, settlement of losses and determination of royalties, decision to change the form of shares from paper to booked and vice versa, on the abolition of trading on the stock exchange, approving the rules on remuneration of members of company bodies, approving a contract for the transfer of a business or its part, cancelling a company or changing its legal form. Minutes are made on the basis of the contents and results of the General Meeting. The Board of Directors is the statutory body of a company and, according to Section 192 of the Commercial Code, it ensures the proper keeping of the company's accounts, submits the financial statements and the annual report for approval to the General Meeting, and ensures their storage in the collection of documents. At least once a year it submits a report on the business activities of the company and the state of its assets to the General Meeting for discussion. The Board of Directors is obliged to submit information to the Supervisory Board at least once a year on the principal intentions of the company's business management for the future, information on the expected development of the company's assets, finances and revenues, and without delay inform the Supervisory Board on matters that may significantly influence development of its business activities, as well as on the assets and liquidity. Upon request, the Board of Directors' members are obliged to attend Supervisory Board meetings and provide additional information. Like directors of a limited liability company, members of the board of directors of a joint stock company are obliged to exercise their powers with due professional care in accordance with the interests of the company and all its shareholders. In exercising their rights, they may not give priority to their interests or those of certain shareholders or third parties over the company's interests. Minutes of the Board of Directors meetings are made. Neither the minimum number of meetings of the Board of Directors nor the number of members of the Board of Directors is stipulated by law. The Supervisory Board of a joint-stock company must have at least three members and, according to Section 197 of the Commercial Code, supervises the exercise of the Board of Directors' powers and the conduct of business activities. Its members are entitled to inspect all documents and records relating to the company's activities and to check the correctness of the accounting records. The members of the Supervisory Board are present at the general meeting of the joint-stock company and are obliged to report on the results of their control activities.

A simple company for shares is regulated by the Commercial Code in Sections from 220h to 220zl. Its capital must be at least 1 Euro. The bodies of this company are the General Meeting, the Board of Directors and the Supervisory Board. A majority of two-thirds of the votes of shareholders present shall be required to approve General Meeting decisions on changes in stock, changes in share 
capital, issue of preference or convertible bonds and cancellation or change in the legal form of a company. The Board of Directors, as a statutory body, manages the activity and acts on behalf of the company. The Supervisory Board oversees the performance of the Board of Directors and the business activities of the company. Its members are elected and dismissed by the General Assembly.

A cooperative is a community of an unrestricted number of persons established for the purpose of doing business or meeting the needs of its members, which must have at least five members. The share capital of the cooperative is made up of the total membership deposits, the minimum amount of which must be 1,250 Euros. The cooperative is a legal entity and its bodies are, pursuant to Section 237 of the Commercial Code, a membership meeting, board of directors, audit committee and other bodies according to the Articles of Association. The supreme body of the cooperative is the meeting of the cooperative members. Its remit includes the amendment of the Articles of Association, the election and dismissal of the members of the Board of Directors and the Audit Commission, approval of the financial statements, decision on the distribution and use of profits and the method of payment of loss; cooperative development concept. The statutory body of the cooperative, according to par. 243, is the Board of Directors. The Board of Directors meets as necessary and fulfils the resolutions of the General Meeting and is responsible for its activities. The members of the Board of Directors are obliged to perform their functions with due care and in accordance with the interests of the cooperative and all its members. The Control Committee is entitled to control all activities of the cooperative and hears the complaints of its members. It shall meet at least quarterly. It has at least three members and is only responsible for the members' meeting; it is independent from the other cooperative bodies. The Audit Commission warns the Board of Directors of any deficiencies found and requires remedy. It expresses its opinion on the financial statements and the proposal for the distribution of profits, respectively, loss compensation. It is entitled to request from the Board of Directors any information on the management of the cooperative, and the Board of Directors is obliged to immediately inform the Control Commission of any facts that may have serious consequences for the management or position of the cooperative and its members. A cooperative with fewer than 50 members may stipulate in its statutes that the powers of the Board of Directors and the Audit Commission shall be fulfilled by the membership meeting.

\section{AIM}

The paper aims to examine the relationship between selected characteristics of the governance process and the ability of governing bodies to perform their core tasks (i.e., Board performance), as well as to model and predict the impact of the selected characteristics of the governance process on the company's financial performance measured by the year-on-year change in return on equity.

\section{METHODOLOGY}

Examination and analyses have been done in accordance with the aforementioned theoretical background of the process approach to the Board of Directors' activities. Research was inspired by Namoga (2011).

The following characteristics of the corporate governance process are examined in the paper:

1) the efforts of the board members;

2) the board cohesiveness;

3) cognitive conflict that regards differences in the judgment of the Board of Directors' members and the way of their solution; and

4) use of knowledge and skills in corporate governance.

The selected characteristics are examined based on a sample of enterprises through survey questions.

Performance of Board members, i.e. their ability to perform basic tasks, is examined through 19 questions in the questionnaire (see Table A1 of the Appendix). In accordance with the theoretical background, these questions are divided into three groups of tasks that are performed by the 
Board:

1) the monitoring and control task is examined through 6 questions;

2) the supporting task is also examined through 6 questions; and

3) the strategic task, which is examined through answers to 7 questions.

All questions are formulated as statements, and the respondents answer whether they completely disagree with the statements (this answer is coded with number 1), disagree, do not know, agree, or fully agree (the answer is coded with 5). Coding is done based on the 5-degree Likert scale. The statements are presented in Table Al (see Appendix). Only one choice is made to answer each question. The responses are ordinary variables.

The respondent sample consists of randomly selected business entities with the headquarters in the Slovak Republic, which, in accordance with the valid legislation of the Slovak Republic, create governing bodies. Specifically, the members of the Board of Directors, the Supervisory Board and the executive managers of these companies were personally addressed. In the first stage of the research, which was carried out during the year 2019 and the results of which are published in this paper, a total of 132 subjects have participated and answered the questions in the survey. 54\% of these respondents represent joint stock companies, 36\% are from limited liability companies, and $10 \%$ are represented by the respondents from cooperatives. Entities have also indicated their identification number in the questionnaire. This data made it possible to obtain additional information from their financial statements and annual reports, from which the year-on-year change in return on equity (ROE) was determined. ROE, as one of the indicators of company performance, is calculated by the ratio of EBIT to equity. The change in the ROE value is calculated between years 2017 and 2018, which are the latest available at the time of processing the research, and is a binary variable for the purposes of this research. The number 1 denotes a year-on-year increase in ROE, the number 0 denotes a ROE decrease.
Several statistical methods are used in this research. The relationship between the board process characteristics as an independent variable and the performance of the Board members as a dependent variable are quantified through the Somers' D (HO: $\mathrm{d}=0 ; H 1: \mathrm{d} \neq 0)$. The impact of the board process attributes on the company performance is quantified through binary logistic regression. The backward stepwise (Wald) method was used to develop the regression model. Independent variables are represented by 17 characteristics of the board process (q14, q18, q19, q23). The dependent variable is the change in ROE. The Nagelkerke R Square test is used to describe the degree of explanation of a dependent variable through the independent variables. The Omnibus tests of model coefficients are used to assess the suitability of model description through logistic regression. The multi-collinearity of the independent, explanatory variables entering the regression model is tested using the Variance Inflation Factor (VIF) with a reference value of 10 . No variable exceeds the VIF reference value. The significance of the interaction between individual predictors and their log transformation is tested through the test of linearity of the logit. A higher significance level was found for all interactions than the level of the selected significance. The independence of random errors is verified by the 1st level autocorrelation test. The influence of independent model variables on the dependent variable is evaluated using the odds ratio. Odds ratio is the ratio of the probability that a phenomenon has occurred and the probability that a phenomenon has not occurred. For variables with an odds ratio higher than 1 , the phenomenon is more likely to occur, i.e., a higher degree of agreement of a respondent with the statement indicates higher probability for the company to record an increase in ROE. Conversely, odds ratio values lower than 1 indicate that with a higher degree of agreement with the statement, the probability of an increase in the ROE will be lower. The logistic regression equation has this formal notation:

$$
\begin{aligned}
& \log \left(\frac{P}{(1-P)}\right)=b_{0}+b_{1} x_{1}+b_{2} x_{2}+\ldots \\
& \ldots+b_{n} x_{n}+\varepsilon,
\end{aligned}
$$

where $P$ is the estimation of the mean level of probability of occurrence of the observed depen- 
dent variable, $b_{0}$ is a constant, $b_{1}, b_{2}$ to $b_{\mathrm{n}}$ are regression coefficients expressed in logits, $x_{1}, x_{2}$ to $x_{n}$ are the values of independent variables, and $\varepsilon$ is a random error.

The hypotheses are tested at the significance level of $\alpha=0.1$. The SPSS statistical program is used for calculations.

\section{EMPIRICAL RESULTS}

The results of the correlation analysis are presented in Table A2 (see Appendix A). The objective of the analysis is to determine how the individual attributes of the board process (q14, q18, q19, q23) affect the performance of the board members through their ability to perform their core tasks (q20, q21, q22). The results that are statistically significant at the selected level of $\alpha$ are indicated in italics in Table A2 of the Appendix.

The impact of board process attributes on the company performance, measured by the year-on-year change in return on equity (ROE), is investigated using binary logistic regression. Covariance of the model will be represented by statements in questions q14, q18, q19, q23. Independent variables are described in Table A1. The dependent variable is a binary formula of the change in ROE. The results of logistic regression are presented in Table 1.
The results of the correlation analysis show that each of the board process attributes that were examined affects at least one board performance attribute at a statistically significant level. All significant correlations have a positive value. The highest number of significant results (15) is detected in the case of statement q14c; 13 significant results are identified in the case of statement q19a; 12 results in statement q23d; and 10 results in statement q14d. Statement q23d significantly correlates with statement q21a. The highest value of Somers' D is recorded amongst statements $\mathrm{q} 22 \mathrm{~d}$ and $\mathrm{q} 14 \mathrm{c}(d=0.625)$, the lowest value is indicated amongst statements q20b and q19b $(d=0.194)$.

Using the backward stepwise Wald method, 15 models with various independent variables were suggested. The results of $15^{\text {th }}$ model, presented in Table 1, show that all selected independent variables q14a, q14d, q18c, q19a, q23a, which are related to the board process in a company, are statistically significant $($ Sig. $<0.1)$ at the selected level $\alpha$.

Hosmer-Lemeshow statistics in Table 2 (Chisquare $=7.605$; $\mathrm{Sig} .=0.473$ ) indicates the model suitability. The values of Cox and Snell R Squared (0.588) and Nagelkerke's R Squared (0.786) (see Table 2) indicate a relatively high degree of explanation of the dependent variable through the model.

Table 1. Logistic regression

Source: Authors' calculations.

\begin{tabular}{|c|c|c|c|c|c|c|c|}
\hline \multirow{2}{*}{ Variables } & \multirow{2}{*}{ B } & \multirow{2}{*}{ S.E. } & \multirow{2}{*}{ Wald } & \multirow{2}{*}{ Sig. } & \multirow{2}{*}{$\operatorname{Exp}(B)$} & \multicolumn{2}{|c|}{ 95\% C.I. for EXP(B) } \\
\hline & & & & & & Lower & Upper \\
\hline$\overline{q 14 a}$ & -5.734 & 2.371 & 5.850 & 0.016 & 0.003 & 0.000 & 0.337 \\
\hline q14d & 4.392 & 1.880 & 5.456 & 0.019 & 80.776 & 2.027 & $3,218.211$ \\
\hline q18c & -2.773 & 1.415 & 3.842 & 0.050 & 0.062 & 0.004 & 1.000 \\
\hline q19a & -2.693 & 1.362 & 3.911 & 0.048 & 0.068 & 0.005 & 0.976 \\
\hline q23a & 4.048 & 1.872 & 4.674 & 0.031 & 57.298 & 1.460 & 2249.029 \\
\hline Constant & 10.284 & 7.890 & 1.699 & 0.192 & $29,246.457$ & - & - \\
\hline
\end{tabular}

Table 2. Hosmer-Lemeshow test results

Source: Authors' calculations.

\begin{tabular}{|c|c|c|c|c|c|c|c|}
\hline & \multicolumn{4}{|c|}{ Hosmer and Lemeshow test } & \multicolumn{3}{|c|}{ Model summary } \\
\hline Method & Step & Chi-square & $\mathrm{df}$ & Sig. & -2 Log likelihood & Cox-Snell R squared & $\begin{array}{c}\text { Nagelkerke's } \\
\text { R squared }\end{array}$ \\
\hline Enter & 0 & 4.405 & 8 & 0.819 & 15.685 & 0.595 & 0.795 \\
\hline Backward & 15 & 7.605 & 8 & 0.473 & 16.247 & 0.588 & 0.786 \\
\hline
\end{tabular}


Table 3. Omnibus tests of model coefficients

Source: Authors' calculations

\begin{tabular}{|c|c|c|c|c|c|}
\hline Method & & & Chi-square & df & Sig. \\
\hline \multirow{3}{*}{ Enter } & \multirow{3}{*}{ Step 0} & Step & 29.790 & 10 & 0.001 \\
\hline & & Block & 29.790 & 10 & 0.001 \\
\hline & & Model & 29.790 & 10 & 0.001 \\
\hline \multirow{3}{*}{ Backward } & \multirow{3}{*}{ Step 15} & Step & 7.560 & 1 & 0.006 \\
\hline & & Block & 29.228 & 5 & 0.000 \\
\hline & & Model & 29.228 & 5 & 0.000 \\
\hline
\end{tabular}

P-values of the Omnibus test of model coefficients (see Table 3, Step 15, Model Sig. $=0.000$ ) inform of low probability of an error of the first kind. Through the output of the Classification table (Table 4), one can see that the use of the selected independent variables increased the estimation rate of ROE change from $54.5 \%$ to $93.9 \%$. The success rate related to classification of the ROE decrease has reduced from $100 \%$ to $94.4 \%$. The success rate of ROE growth classification has increased from $0 \%$ to $93.3 \%$.

Table 4. Classification table

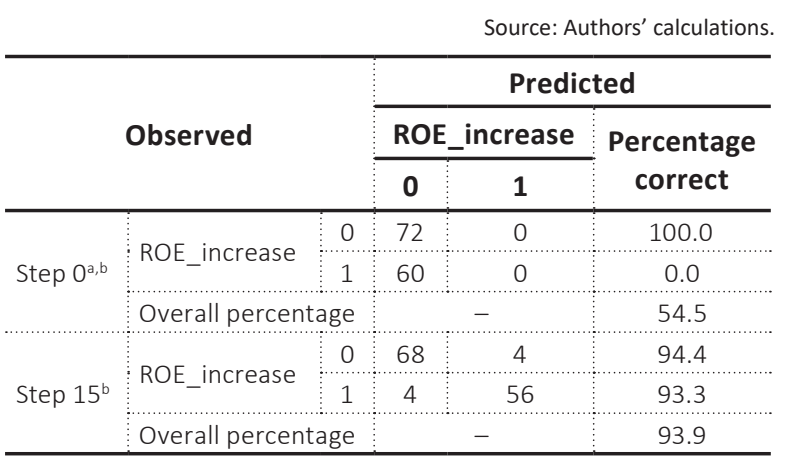

Note: ${ }^{\text {a. }}$ Constant is included in the model; ${ }^{\text {b. }}$ the cut value is .500 .

Table 5. Coefficients ${ }^{\mathrm{a}}$

Source: Authors' calculation.

\begin{tabular}{|c|c|c|c|}
\hline & \multirow{2}{*}{ Model } & \multicolumn{2}{|c|}{ Collinearity statistics } \\
\hline & & Tolerance & VIF \\
\hline \multirow{5}{*}{15} & q18c & .783 & 1.277 \\
\hline & q19a & .799 & 1.252 \\
\hline & q23a & .736 & 1.358 \\
\hline & q14a & .724 & 1.382 \\
\hline & $q 14 d$ & .804 & 1.243 \\
\hline
\end{tabular}

Note: ${ }^{\text {a. }}$ Dependent variable: ROE_increase.

The prerequisites to develop the model have been successfully fulfilled. The model was tested for multi-collinearity and the test results are presented in Table 5; none of the VIF values exceeds the reference value, while the highest VIF (1.382) has been identified in the statement q14a. Through the auto-correlation test of the 1st degree of standardized residues, the independence of random errors has been detected. The results of testing for linearity of the logit, given in Table 6 , show the existence of a linear relationship between all independent variables and their logarithmic expression (Sig. > 0.1).

The value of the regression coefficients expressed in logits is denoted by symbol B in Table 1 . Negative coefficients indicate that the chances of an increase in ROE in the company decrease as the agreement with the statement increases. The Exp. (B) (i.e., odds ratio) value indicates the chance. Negative coefficients for statements q14a, q18c and q19a point to a possible decrease in the year-onyear value of ROE in case of evaluation of relevant board processes by higher points, i.e. through a fully expressed agreement with the statement. In all three cases, however, there is only a very low value of this chance (see Exp. (B)). The other independent variables included in the model $(\mathrm{q} 14 \mathrm{~d}$, q23a) have positive regression coefficients, which means that with the growing agreement with the statement that is related to the board process, there is a higher possibility that the enterprise may record a year-on-year increase in ROE. In companies where information flows quickly and without loss of quality (q14d), the chance to achieve a growth in ROE is 80.8 times higher compared to companies that have problems with the flow and quality of information needed for governance. Mutual respect and confidence (q23a) may increase the chances to achieve an ROE increase by up to 57.3 times.

By substituting the value of regression coefficients into equation (1), the following binary logistic model was obtained: 
Table 6. Variables in the equation

\begin{tabular}{|c|c|c|c|c|c|c|c|}
\hline & & B & S.E. & Wald & df & Sig. & $\operatorname{Exp}(B)$ \\
\hline \multirow{11}{*}{ Step $1^{\mathrm{a}}$} & q14a & -62.566 & 198151.901 & .000 & 1 & 1.000 & .000 \\
\hline & q14d & 13.524 & 18.098 & .558 & 1 & .455 & $746,795.174$ \\
\hline & q18c & -11.122 & 8.306 & 1.793 & 1 & .181 & .000 \\
\hline & q19a & -14.387 & 15.906 & .818 & 1 & .366 & .000 \\
\hline & q23a & 5.706 & 18.028 & .100 & 1 & .752 & 300.578 \\
\hline & LNq14a by q14a & 22.727 & $79,197.019$ & .000 & 1 & 1.000 & $7,413,640,269.429$ \\
\hline & LNq14d by q14d & -3.918 & 7.627 & .264 & 1 & .607 & .020 \\
\hline & LNq18c by q18c & 3.771 & 3.770 & 1.000 & 1 & .317 & 43.430 \\
\hline & LNq19a by q19a & 5.081 & 6.620 & .589 & 1 & .443 & 161.015 \\
\hline & LNq23a by q23a & -.711 & 7.752 & .008 & 1 & .927 & .491 \\
\hline & Constant & 124.813 & $353,446.075$ & .000 & 1 & 1.000 & $1.61 \mathrm{E}+54$ \\
\hline
\end{tabular}

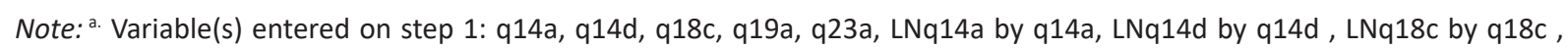
LNq19a by q19a, LNq23a by q23a .

$\log \left(\frac{P}{(1-P)}\right)=10.284-5.734 q 14 a+$

$+4.392 q 14 d-2.773 q 18 c-$

$-2.693 q 19 a+4.048 q 23 a+\varepsilon$.

This binary logistic model can be used to predict the change in ROE of business entities.

The decrease in ROE can be predicted for entities whose governing bodies fully agree with statements q14a, q18c and q19a and completely disagree with statements q14d and q23a. The model predictions can be seen in Table 7. To predict a decline in ROE, the statements whose $\operatorname{Exp}(\mathrm{B})$ values (in Table 1) are higher than 1 were lowered with a low rating (strongly disagree). On the other hand, the statements whose $\operatorname{Exp}(\mathrm{B})$ values are lower than 1 were strengthened with a high rating (I fully agree). Respondents who fully agree with statements q14d and q23a and at the same time strongly disagree with statements q14a, q18c and q19a, can expect growth of ROE.

From the answers to questions q14a, q14d, q18c, q19a and q23a, mean, mode, median, minimum and maximum were found, and the prediction of ROE change for each was created. The results are given in Table 7.

\section{DISCUSSION}

This research is one of the first of its kind to be conducted in Slovakia. Therefore, comparison of its results with other statistically comparable data is limited.

Many different corporate governance characteristics have been researched and examined. Khanchel (2007) analyzed board size, board composition

Table 7. Descriptive statistics and case summaries

\begin{tabular}{|c|c|c|c|c|c|c|}
\hline & \multicolumn{5}{|c|}{ Fictitious respondents' answer ${ }^{s}$} & \multirow{2}{*}{$\begin{array}{c}\text { Predicted } \\
\text { group }^{b}\end{array}$} \\
\hline & q14a & q14d & q18c & q19a & q23a & \\
\hline Mean & 4.27 & 3.91 & 3.73 & 3.97 & 4.15 & 0 \\
\hline Median & 4 & 4 & 4 & 4 & 4 & 0 \\
\hline Mode & 4 & 4 & $3^{a}$ & 4 & 4 & 1 \\
\hline Mode & 4 & 4 & $4^{\mathrm{a}}$ & 4 & 4 & 1 \\
\hline Minimum & 3 & 2 & 2 & 1 & 3 & 1 \\
\hline Maximum & 5 & 5 & 5 & 5 & 5 & 0 \\
\hline Extreme answers to increase ROE & 1 & 5 & 1 & 1 & 5 & 1 \\
\hline Extreme answers to decrease ROE & 5 & 1 & 5 & 5 & 1 & 0 \\
\hline
\end{tabular}

Note: ${ }^{\text {a. }}$ Multiple modes exist. ${ }^{\text {b. }} 0$ means an ROE decrease, 1 means an ROE increase. ${ }^{c .}$ Completely disagree with the statements (this answer is coded with number 1), disagree (code 2), do not know (code 3), agree (code 4), and fully agree (the answer is coded with 5). 
and board meetings, CEO duality, independence of committees, competence of audit committee members, reputation of auditors, audit committee meetings, and compensation and nominating committee meetings. Using a simple linear ranking method, the researcher has constructed four indices of a governance rating.

The influence of the Board of Directors on firm performance has been the primary focus of organizational behavioral research (Deutsch, 2005; Kouaib \& Jarboui, 2016; Pham, Suchard, \& Zien, 2011; Yilmaz \& Mazzeo, 2014). Various board characteristics have been examined and acknowledged as effective factors in creating value for shareholders. Although this line of research facilitates discussion of the link between the board of directors and company performance, with return on assets (ROA), return on equity (ROE), and Tobin's $Q$ being the measures that are generally used to represent short-term performance (Ararat, Aksu, \& Cetin, 2015; Bhagat \& Bolton, 2008; Kaczmarek, Kimino, \& Pye, 2012; Masulis, Wang, \& Xie, 2012; Pham, Suchard, \& Zien, 2011; Welch, 2003), evidence on whether and how the board of directors contributes to company long-term survival and prosperity is scarce.

L. He, R. He, and Evans (2020) confirm that boards play an important role in company investment decision making. Board effectiveness is a function of board potential and board dynamics (Macus, 2008). The internal processes of how boards enable the resources to be used effectively are critical for the boards to produce positive organizational outcomes (L. He, R. He, \& Evans, 2020).

Corporate governance examination is significant from a theoretical point of view, but the practical benefit is more important. Results in the research reflect that corporate governance has a significant impact on performance, measured in terms of return on equity. The relationship between the selected CG process attributes and board performance attributes was confirmed at a statistically significant level. The achieved results are important for ownership rights by management bodies. There is a need for business owners to establish clear rules for business management and compliance monitoring.

\section{CONCLUSION}

Most of the studies conducted apply a direct approach to the performance of Board of Directors, through which a direct relationship between the board of directors and corporate performance is examined. This study is based on process approach, which relates to decision-making activities and the behavior of its members that may affect the Board's ability to perform its tasks. The results of the correlation analysis between the selected CG process attributes and board performance attributes show that each of the board process attributes examined affects at least one board performance attribute at a statistically significant level. All significant correlations have a positive value. Formulated binary logistic model can be used to predict the change in business entities' ROE. Quantifying independent variables increased the estimate rate of ROE change from $54.5 \%$ to $93.9 \%$. The success rate related to classification of an ROE decrease is $94.4 \%$ and the success rate of the ROE growth classification is $93.3 \%$.

Although the research was inspired by Namoga, the form of a survey on a sample of companies in the Slovak Republic, through which it was conducted, is a novelty, as well as the modelling of the impact of selected attributes of corporate governance on ROE change. The space for further research can be seen in expanding the research sample by other companies, as well as in repeating the study to compare changes in the results achieved.

Without doubt, the authors are aware of the fact that modelling of corporate governance and board processes, as well as the performance of corporate governance bodies as a whole, has its limits and limitations. This may have resulted from the amount, quality and structure of the available data. At the same time, this might also be influenced by the capability of the interviewees to assess the situation objectively and without prejudices. Moreover, the relevant legislation may have an influence as 
well. In the Slovak Republic, this legislation primarily concerns the Commercial Code and the Act on Accounting, through which the obligations, competences of the management, and the governing bodies are defined. The documents also determine the basic conditions and laws for the disclosure of information that is related to confidential materials, facts and events in companies, as well as their business results. Efforts to unify the conditions are made in large companies in the form of codification of corporate governance principles. However, these are mostly recommendations in character, and thus, they are not required to be implemented by smaller joint stock companies. Despite the OECD's efforts to formulate recommendations for corporate governance, these principles are not sufficient to assess board processes and the performance of governance bodies. It is assumed that it should be a comprehensive and detailed material, which should develop some convenient mechanism to measure the efficiency of board processes and the performance of the Board of Directors' members. Due to the uniqueness of many processes, their unification is problematic. The Commercial Code authorizes the General Meeting to approve the remuneration rules for the members of the company bodies. However, these rules should be based on appropriately chosen qualitative and quantitative characteristics that can adequately reflect the qualitative level of corporate governance and the board process. It should be noted, however, that the development of such a mechanism is a rather intricate task.

\section{AUTHOR CONTRIBUTIONS}

Conceptualization: Janka Grofcikova.

Data curation: Janka Grofcikova.

Formal analysis: Janka Grofcikova.

Funding acquisition: Hussam Musa.

Investigation: Janka Grofcikova.

Methodology: Janka Grofcikova.

Project administration: Hussam Musa, Janka Grofcikova.

Resources: Janka Grofcikova.

Software: Janka Grofcikova.

Supervision: Hussam Musa, Janka Grofcikova.

Validation: Janka Grofcikova.

Visualization: Janka Grofcikova.

Writing - original draft: Janka Grofcikova.

Writing - review \& editing: Janka Grofcikova.

\section{ACKNOWLEDGMENT}

This paper has been supported by the Scientific Grant Agency of Slovak Republic under the project VEGA No. 1/0749/18 "Research on the application of corporate governance principles in companies in Slovakia". The authors would like to express their gratitude to the Scientific Grant Agency of The Ministry of Education, Science, Research and Sport of the Slovak Republic for financial support of this research and publication.

\section{REFERENCES}

1. Akinleye, G. T., Olarewaju, O. M., Fajuyagbe, B. S. (2019). Corporate governance and financial performance: an empirical analysis of selected multinational firms in Nigeria. Problems and Perspectives in Management, 17(1), 11-18. http://dx.doi.org/10.21511/ ppm.17(1).2019.02
2. Amason, A., \& Sapienza, H. (1997). The effects of top management team size and interaction norms on cognitive and affective conflict. Journal of Management, 23(4), 495-516. https://doi. org/10.1177/014920639702300401

3. Ararat, M., \& Ugur, M. (2003). Corporate governance in Turkey:
An overview and some policy recommendations. Corporate governance: An International Review, 3(1), 58-75. http://dx.doi. org/10.1108/14720700310459863

4. Ararat, M., Aksu, M., \& Cetin, A. T. (2015). How Board Diversity Affects Firm Performance in Emerging Markets: Evidence on Channels 
in Controlled Firms. Corporate Governance: An International Review, 23(2), 83-103. http://dx.doi. org/10.1111/corg. 12103

5. Bhagat, S., \& Bolton, B. (2008). Corporate governance and firm performance. Journal of Corporate Finance, 14(3), 257-273. http:// dx.doi.org/10.1016/j.jcorpfin.2008.03.006

6. Boeker, W., \& Goodstein, J. (1991). Organizational performance and adaptation: Effects of environment and performance on changes in board composition. Academy of Management Journal, 34(4), 805826. Retrieved from https://psycnet. apa.org/record/1992-14808-001

7. Boyd, B. (1990). Corporate linkages and organizational environment A test of the resource dependence model. Strategic Management Journal, 11(6), 419-430. https://doi. org/10.1002/smj.4250110602

8. Cadbury, A. (1992). Report of the Committee on the Financial Aspects of Corporate Governance. London: Gee \& Co. Ltd. Retrieved from https://ecgi.global/sites/default/ files/codes/documents/cadbury.pdf

9. Conyon, M. J., \& Peck, S. I. (1998). Board size and corporate performance: evidence form European countries. The European Journal of Finance, 4(3), 291-304. https://doi. org/10.1080/135184798337317

10. Daily, C. M., \& Dalton, D. R. (1993). Board of directors leadership and structure: Control and performance implications. Entrepreneurship Theory and Practice, 17(3), 65-81. https://doi. org/10.1177/104225879301700305

11. Daily, C. M., \& Dalton, D. R. (1994). Bankruptcy and corporate governance: The impact of board composition and structure. Academy of Management Journal, 37(6), 1603-1617. https://doi. org $/ 10.5465 / 256801$

12. Dalton, D. R., Daily, C. M., Ellstrand, A. E., \& Johnson, J. L. (1998). Meta-analytic review of board composition leadership structure and financial performance. Strategic Management Journal, 19(3), 269-290. https:// doi.org/10.1002/(SICI)1097-
0266(199803)19:3<269::AID-

SMJ950>3.0.CO;2-K

13. Deutsch, Y. (2005). The Impact of Board Composition on Firms' Critical Decisions: A Meta-Analytic Review. Journal of Management, 31(3), 424-444. http://dx.doi. org/10.1177/0149206304272185

14. Freire, F. (2019). Duality CEOChairman and its relation with the effectiveness of the board control. Problems and Perspectives in Management, 17(4), 239-

251. http://dx.doi.org/10.21511/ ppm.17(4).2019.20

15. Gillan, S. L. (2006). Recent developments in corporate governance: An overview. Journal of Corporate Finance, 12(3), 381-402. https://doi. org/10.1016/j.jcorpfin.2005.11.002

16. Gillan, S. L., \& Starks, L. T. (1998). A survey of shareholder activism: Motivation and empirical evidence. Contemporary Finance Digest, 2(3), 10-34. http://dx.doi.org/10.2139/ ssrn.663523

17. Gopinath, C., Siciliano, J. I., \& Murray, R. L. (1994). Changing role of the board of directors: In search of a new strategic identity. The Mid-Atlantic Journal of Business, 30(2), 175-185.

18. Grofcikova, J. (2016). The use of financial analysis indicators for the monitoring of company financial situation and elimination of financial risk. Managing and Modelling of Financial Risks 2016. 8th International Scientific Conference. Ostrava.

19. Grofcikova. J., \& Izakova, K. (2018). Corporate governance and firm performance in Slovakia. Proceedings of the 18th International Scientific Conference Globalization and its Socio-Economic Consequences. Rajecké Teplice. 532-539. Retrieved from https:// globalization.uniza.sk/wp-content/ uploads/2018/12/proceedings_globalization_2018_part_5.pdf

20. He, L., He, R., \& Evans, E. (2020). Board influence on a firm's long-term success: Australian evidence. Journal of Behavioral and Experimental Finance, 27, 100327. http://dx.doi.org/10.1016/j. jbef.2020.100327
21. Hung, H. (1998). A typology of the theories of the roles of governing boards. Corporate Governance: An International Review, 6(2), 101-111. https://doi.org/10.1111/14678683.00089

22. Jackling, B., \& Johl, S. (2009). Board structure and firm performance: evidence form India's top companies. Corporate Governance: An International Review, 17(4), 492509. https://doi.org/10.1111/j.14678683.2009.00760.x

23. Jensen, M. C. (1993). The modern industrial revolution, exit, and the failure of internal control system. Journal of Finance, 48(3), 831-880. https://doi. org/10.1111/j.1540-6261.1993. tb04022.x

24. Jensen, M. C., \& Meckling, W. H. (1976). Theory of the firm: Managerial behavior. Agency costs and ownership structure. Journal of Financial Economics, 3(4), 305-360. https://doi.org/10.1016/0304405X(76)90026-X

25. Johnson, J. L., Daily, C. M., \& Ellstrand, A. E. (1996). Board of directors: a review and research agenda. Journal of Management, 22(3), 409-438. https://doi.org/10.1016/ S0149-2063(96)90031-8

26. Judge, W. Q., \& Zeithaml, C. P. (1992). Institutional and strategic choice perspectives on board involvement in the strategic decision process. Academy of Management Journal, 35(4), 766-794. Retrieved from https://psycnet.apa.org/record/1993-15671-001

27. Kaczmarek, S., Kimino, S., \& Pye, A. (2012). Board Task-related Faultlines and Firm Performance: A Decade of Evidence. Corporate Governance: An International Review, 20(4), 337-351. http:// dx.doi.org/10.1111/j.14678683.2011.00895.x

28. Khanchel, I. (2007). Corporate governance: measurement and determinant analysis. Managerial Auditing Journal, 22(8), 740-760. http://dx.doi. org/10.1108/02686900710819625

29. Kiel, G. C., \& Nicholson, G. J. (2003). Board composition and corporate performance: How the 
Australian experience informs contrasting theories of corporate governance. Corporate Governance: An International Review, 11(3), 189205. https://doi.org/10.1111/14678683.00318

30. Kliestik, T., Valaskova, K., Lazaroiu, G., Kovacova, M., \& Vrbka, J. (2020). Remaining Financially Healthy and Competitive: The Role of Financial Predictors. Journal of Competitiveness, 12(1), 74-92. https://doi.org/10.7441/ joc.2020.01.05

31. Kouaib, A., \& Jarboui, A. (2016). Real earnings management in innovative firms: Does CEO profile make a difference? Journal of Behavioral and Experimental Finance, 12, 40-54. http://dx.doi. org/10.1016/j.jbef.2016.09.002

32. Lawrence, B. (1997). The black box of organizational demography. Organization Science, 8(1), 1-22. https://doi.org/10.1287/orsc.8.1.1

33. Legislation of the Slovak Republic. (1991). Commercial Code No. 513/1991 collected as amended. Retrieved from https://is.muni.cz/ el/1422/jaro2013/SOC038/um/ Obchodny_zakonnik_513_1991_v_ anglickom_jazyku.pdf

34. Legislation of the Slovak Republic. (2002). Act No. 431/2002 Coll. on Accounting. Retrieved from https:// www.mfsr.sk/en/taxes-customsaccounting/accounting/laws/

35. Levrau, A., \& Van Den Berghe, L. (2007). Corporate governance and board effectiveness: Beyond formalism (Working Papers of Faculty of Economics and Business Administration No. 07/448). Ghent University, Belgium. Retrieved from http://wps-feb.ugent.be/ Papers/wp_07_448.pdf

36. Maassen, G. F. (1999). An international comparison of corporate governance models (3rd ed.). Amsterdam: Spencer Stuart.

37. Macus, M. (2008). Board capability: An interactions perspective on boards of directors and firm performance. International Studies of Management \& Organization, 38(3), 98-116. http://dx.doi.org/ https://doi.org/10.2753/IMO00208825380304
38. Masulis, R. W., Wang, C., \& Xie, F. (2012). Globalizing the boardroom - The effects of foreign directors on corporate governance and firm performance. Journal of Accounting and Economics, 53(3), 527-554. http://dx.doi.org/10.1016/j.jacceco.2011.12.003

39. Melone, N. (1994). Reasoning in the executive suite: The influence of role/experience-based expertise on decision processes of corporate executives. Organization $\mathrm{Sci}$ ence, 5(3), 438-455. http://dx.doi. org/10.1287/orsc.5.3.438

40. Mitton, T. (2002). A cross-firm analysis of the impact of corporate governance on the East Asian financial crisis. Journal of Financial Economics, 64(2), 215-241. https://doi.org/10.1016/S0304405X(02)00076-4

41. Musa, H., Rech, F., \& Musova, Z. (2019). The role of corporate governance in debt and dividend policies: case of Slovakia. Investment Management and Financial Innovations, 16(2), 206-217. http://dx.doi. org/10.21511/imfi.16(2).2019.18

42. Namoga, M. O. (2011). Corporate governance and board performance: Empirical Evidence form Pacific Island Countries (Ph.D. Thesis). James Cook University, Australia. Retrieved from https://researchonline.jcu.edu.au/18929/2/02whole. pdf

43. OECD. (1998). Corporate governance: Improving competitiveness and access to capital in global markets. A report to the OECD by the business sector advisory group on corporate governance. Paris: OECD Publishing. http://dx.doi. org/10.1787/9789264162709-en

44. OECD. (2015). G20/OECD Principles of corporate governance. Paris: OECD Publishing. http://dx.doi. org/10.1787/9789264236882-en

45. Ong, C. H., \& Wan, D. T. W. (2008) Three conceptual models of board role performance. Corporate Governance: An International Review, 8(3), 317-329. https://doi. org/10.1108/14720700810879196

46. Pearce, J. A., \& Zahra, S. A. (1992). Board composition from a strategic contingency perspec- tive. Journal of Management Studies, 29(4), 411-438. https:// doi.org/10.1111/j.1467-6486.1992. tb00672.x

47. Pettigrew, A. M. (1992). On studying managerial elites. Strategic Management Journal, 13(2), 163-182. https://doi.org/10.1002/ smj.4250130911

48. Pham, P. K., Suchard, J. A., \& Zien, J. (2011). Corporate governance and alternative performance measures: evidence from Australian firms. Australian Journal of Management, 36(3), 371-386. https://doi. org/10.1177/0312896211413035

49. Priem, R., Lyon, D. W., \& Dess, G. (1999). Inherent limitations of demographic proxiesin top management team heterogeneity research. Journal of Management, 25(6), 935-953. https://doi. org/10.1177/014920639902500607

50. Shleifer, A., \& Vishny, R. W. (1997). A Survey of Corporate Governance. Journal of Finance, 52(2), 737-783. https://doi. org/10.1111/j.1540-6261.1997. tb04820.x

51. Velte, P. (2018). Is audit committee expertise connected with increased readability of integrated reports: Evidence from EU companies. Problems and Perspectives in Management, 16(2), 23-41. https://doi. org/10.21511/ppm.16(2).2018.03

52. Welch, E. (2003). The Relationship Between Ownership Structure and Performance in Listed Australian Companies. Australian Journal of Management, 28(3), 287-305. http://dx.doi. org/10.1177/031289620302800304

53. Yermack, D. (1996). Higher market valuation of companies with a small board of directors. Journal of Financial Economics, 40(2), 185211. https://doi.org/10.1016/0304405X(95)00844-5

54. Yilmaz, N., \& Mazzeo, M. A. (2014). The effect of CEO overconfidence on turnover abnormal returns. Journal of Behavioral and Experimental Finance, 3, 1121. http://dx.doi.org/10.1016/j. jbef.2014.07.001 


\section{APPENDIX A}

Table A1. Description of variables

Source: Authors' formulations.

\begin{tabular}{|c|c|c|c|}
\hline & & Symbol & Statements in questionnaire \\
\hline \multirow{17}{*}{$\begin{array}{l}\text { Corporate } \\
\text { governance } \\
\text { (board) process } \\
\text { attributes }\end{array}$} & \multirow{5}{*}{ Effort } & q19a & Before meetings, the BoD shall carefully review the information provided by the company \\
\hline & & q19b & The board often examines (is interested in) the situation in areas of importance to society \\
\hline & & q19c & Members make notes during meetings \\
\hline & & q19d & Members of the BoD emphasize the activities of the BoD and the whole company \\
\hline & & q19e & $\begin{array}{l}\text { When assigning specific tasks, Board members have a positive attitude towards the } \\
\text { workload of the company }\end{array}$ \\
\hline & \multirow{3}{*}{$\begin{array}{l}\text { Cognitive } \\
\text { conflict }\end{array}$} & q18a & The BoD reviews the views of individual members before taking a final decision \\
\hline & & $\mathrm{q} 18 \mathrm{~b}$ & Decisions of the BoD are taken in a friendly atmosphere \\
\hline & & q18c & The BoD meetings are open and honest \\
\hline & \multirow{5}{*}{$\begin{array}{l}\text { Board } \\
\text { cohesiveness }\end{array}$} & q23a & The members of the BoD respect and trust each other \\
\hline & & $q 23 b$ & The members of the BoD also meet with each other outside the meetings of the BoD \\
\hline & & $q 23 c$ & The BoD receives feedback from directors for decision-making \\
\hline & & $\mathrm{q} 23 \mathrm{~d}$ & The BoD will receive assistance from the directors in making decisions \\
\hline & & q23e & The directors shall cooperate with each other \\
\hline & \multirow{4}{*}{$\begin{array}{l}\text { Use of } \\
\text { skills and } \\
\text { knowledge }\end{array}$} & q14a & The board members are aware of the areas of their experience \\
\hline & & q14b & When discussing a problem, the most informative members have the greatest impact \\
\hline & & q14c & $\begin{array}{l}\text { The delegation of tasks shall be in accordance with the knowledge and responsibility of } \\
\text { the members responsible for the task }\end{array}$ \\
\hline & & q14d & Information flows between members quickly and without loss of quality \\
\hline \multirow{19}{*}{$\begin{array}{l}\text { Boards } \\
\text { performance } \\
\text { attributes }\end{array}$} & \multirow{6}{*}{$\begin{array}{l}\text { Monitoring } \\
\text { and control } \\
\text { roles }\end{array}$} & q20a & The BoD ratifies and monitors the strategic decisions of top management \\
\hline & & q20b & The Management Board develops performance targets for management \\
\hline & & q20c & The Board formally evaluates the performance of the company's top managers \\
\hline & & q20d & The Board analyzes financial information on important issues and trends \\
\hline & & q20e & The Board analyzes the budget allocation in line with performance \\
\hline & & q20f & The BoD assesses the company's performance against the strategic plan \\
\hline & \multirow{6}{*}{ Service roles } & q21a & $\begin{array}{l}\text { The CEO, Managing Directors and Managers ask the BoD for help in formulating their } \\
\text { corporate strategy }\end{array}$ \\
\hline & & $q 21 b$ & The BoD is an effective controller for strategic issues management \\
\hline & & q21c & $\begin{array}{l}\text { The BoD also provides management advice and recommendations in discussions outside } \\
\text { Board and Committee meetings }\end{array}$ \\
\hline & & q21d & The BoD takes into account the legitimate interests of other stakeholders in the company \\
\hline & & q21e & The Board ensures communication with stakeholders and the general public \\
\hline & & q21f & The Board promotes goodwill and support from relevant stakeholders \\
\hline & \multirow{7}{*}{ Strategic roles } & q22a & The BoD formulates the company's mission \\
\hline & & $q 22 b$ & The BoD carries out an internal analysis of the company's strengths and weaknesses \\
\hline & & q22c & The BoD carries out an external analysis of opportunities and threats to society \\
\hline & & $\mathrm{q} 22 \mathrm{~d}$ & The BoD is involved in the strategic planning process of the company \\
\hline & & q22e & The Board communicates the strategic direction of the company throughout the company \\
\hline & & q22f & $\begin{array}{l}\text { The BoD adopts the plans of the Managing Director (Executive Directors) to implement } \\
\text { the strategy }\end{array}$ \\
\hline & & q22g & The Board compares the Strategic Plan with comparable industry data \\
\hline
\end{tabular}

Note: BoD - Board of Directors. 
Source: Authors' calculations.

\begin{tabular}{|c|c|c|c|c|c|c|c|c|c|c|c|c|c|c|c|c|c|c|c|c|}
\hline \multirow{2}{*}{\multicolumn{2}{|c|}{$\begin{array}{c}\text { Somers' } \\
\text { D (Sig) }\end{array}$}} & \multicolumn{6}{|c|}{ Monitoring and control roles } & \multicolumn{6}{|c|}{ Service roles } & \multicolumn{7}{|c|}{ Strategic roles } \\
\hline & & \multirow{2}{*}{$\begin{array}{c}\mathbf{q 2 0 a} \\
.291 \\
(.016)\end{array}$} & \multirow{2}{*}{$\begin{array}{c}\mathbf{q 2 0 b} \\
.297 \\
(.005)\end{array}$} & \multirow{2}{*}{$\begin{array}{c}\mathbf{q 2 0 c} \\
.257 \\
(.100)\end{array}$} & \multirow{2}{*}{$\begin{array}{c}\mathrm{q} 20 \mathrm{~d} \\
.508 \\
(.001)\end{array}$} & \multirow{2}{*}{$\begin{array}{c}\mathbf{q 2 0 e} \\
.183 \\
(.313)\end{array}$} & \multirow{2}{*}{$\begin{array}{c}\mathbf{q 2 0 f} \\
.483 \\
(.000)\end{array}$} & \multirow{2}{*}{$\begin{array}{c}\mathbf{q 2 1 a} \\
.263 \\
(.125)\end{array}$} & \multirow{2}{*}{$\begin{array}{c}\mathbf{q 2 1 b} \\
.455 \\
(.005)\end{array}$} & \multirow{2}{*}{$\begin{array}{c}\mathbf{q 2 1 c} \\
.259 \\
(.018)\end{array}$} & \multirow{2}{*}{$\begin{array}{l}\mathbf{q 2 1 d} \\
.378 \\
(.012)\end{array}$} & \multirow{2}{*}{$\begin{array}{c}\mathbf{q 2 1 e} \\
.238 \\
(.135)\end{array}$} & \multirow{2}{*}{$\begin{array}{c}\mathbf{q 2 1 f} \\
.149 \\
(.415)\end{array}$} & \multirow{2}{*}{$\begin{array}{c}\text { q22a } \\
.471 \\
(.000)\end{array}$} & \multirow{2}{*}{$\begin{array}{c}\mathbf{q 2 2 b} \\
.443 \\
(.002)\end{array}$} & \multirow{2}{*}{$\begin{array}{c}\mathbf{q 2 2 c} \\
.393 \\
(.052)\end{array}$} & \multirow{2}{*}{$\begin{array}{c}\text { q22d } \\
.440 \\
(.005)\end{array}$} & \multirow{2}{*}{$\begin{array}{c}\mathbf{q 2 2 e} \\
.158 \\
(.293)\end{array}$} & \multirow{2}{*}{$\begin{array}{c}\mathbf{q 2 2 f} \\
.118 \\
(.477)\end{array}$} & \multirow{2}{*}{$\begin{array}{c}\mathbf{q 2 2 g} \\
.294 \\
(.091)\end{array}$} \\
\hline & q19a & & & & & & & & & & & & & & & & & & & \\
\hline \multirow{4}{*}{$\begin{array}{l}\text { tัँ } \\
\text { 离 }\end{array}$} & $q 19 b$ & $\begin{array}{c}.332 \\
(.083)\end{array}$ & $\begin{array}{l}.194 \\
(.074)\end{array}$ & $\begin{array}{c}.166 \\
(.309)\end{array}$ & $\begin{array}{c}.466 \\
(.046)\end{array}$ & $\begin{array}{c}.279 \\
(.188)\end{array}$ & $\begin{array}{c}.324 \\
(.073)\end{array}$ & $\begin{array}{l}-.028 \\
(.895)\end{array}$ & $\begin{array}{c}.437 \\
(.007)\end{array}$ & $\begin{array}{c}.312 \\
(.118)\end{array}$ & $\begin{array}{c}.453 \\
(.033)\end{array}$ & $\begin{array}{c}.259 \\
(.153) \\
\end{array}$ & $\begin{array}{c}.223 \\
(.217)\end{array}$ & $\begin{array}{c}.615 \\
(.000)\end{array}$ & $\begin{array}{c}.377 \\
(.023)\end{array}$ & $\begin{array}{c}.271 \\
(.271)\end{array}$ & $\begin{array}{c}.445 \\
(.027)\end{array}$ & $\begin{array}{l}.024 \\
(.916)\end{array}$ & $\begin{array}{c}.073 \\
(.712)\end{array}$ & $\begin{array}{c}.170 \\
(.406)\end{array}$ \\
\hline & q19c & $\begin{array}{l}.167 \\
(.341)\end{array}$ & $\begin{array}{c}.117 \\
(.398)\end{array}$ & $\begin{array}{l}.067 \\
(.668)\end{array}$ & $\begin{array}{c}.375 \\
(.009)\end{array}$ & $\begin{array}{c}.117 \\
(.339)\end{array}$ & $\begin{array}{c}.367 \\
(.006)\end{array}$ & $\begin{array}{c}.085 \\
(.587)\end{array}$ & $\begin{array}{c}.352 \\
(.021)\end{array}$ & $\begin{array}{c}.161 \\
(.251)\end{array}$ & $\begin{array}{c}.182 \\
(.322)\end{array}$ & $\begin{array}{c}.185 \\
(.192)\end{array}$ & $\begin{array}{c}.097 \\
(.583)\end{array}$ & $\begin{array}{l}.205 \\
(.086)\end{array}$ & $\begin{array}{c}.358 \\
(.008)\end{array}$ & $\begin{array}{c}.302 \\
(.029)\end{array}$ & $\begin{array}{c}.261 \\
(.054)\end{array}$ & $\begin{array}{l}.138 \\
(.311)\end{array}$ & & \\
\hline & q19d & $\begin{array}{l}.414 \\
(.003)\end{array}$ & $\begin{array}{l}.283 \\
(.030)\end{array}$ & $\begin{array}{c}.220 \\
(.206)\end{array}$ & $\begin{array}{l}.312 \\
(.051)\end{array}$ & $\begin{array}{c}.182 \\
(.148)\end{array}$ & $\begin{array}{c}.061 \\
(.712)\end{array}$ & $\begin{array}{l}.099 \\
(.492)\end{array}$ & $\begin{array}{c}.197 \\
(.235)\end{array}$ & $\begin{array}{c}.124 \\
(.335)\end{array}$ & $\begin{array}{l}.360 \\
(.018)\end{array}$ & $\begin{array}{c}.143 \\
(.336)\end{array}$ & $\begin{array}{c}.217 \\
(.139)\end{array}$ & $\begin{array}{c}.455 \\
(.002)\end{array}$ & $\begin{array}{c}.134 \\
(.355)\end{array}$ & $\begin{array}{l}.000 \\
(1.00)\end{array}$ & $\begin{array}{l}.315 \\
(.030)\end{array}$ & $\begin{array}{c}.102 \\
(.553)\end{array}$ & $\begin{array}{l}.213 \\
.248)\end{array}$ & $\begin{array}{l}.156 \\
(.352)\end{array}$ \\
\hline & q19e & $\begin{array}{c}.203 \\
(.164)\end{array}$ & $\begin{array}{l}.257 \\
(.055)\end{array}$ & $\begin{array}{c}.024 \\
(.878)\end{array}$ & $\begin{array}{l}.331 \\
(.019)\end{array}$ & $\begin{array}{c}.215 \\
(.065)\end{array}$ & .054 & $\begin{array}{l}.143 \\
(.371)\end{array}$ & $\begin{array}{c}.182 \\
(.265)\end{array}$ & $\begin{array}{c}.149 \\
(.260)\end{array}$ & $\begin{array}{l}.116 \\
(.473)\end{array}$ & $\begin{array}{c}.191 \\
(.192)\end{array}$ & $\begin{array}{c}.349 \\
(.022)\end{array}$ & $\begin{array}{l}.209 \\
(.073)\end{array}$ & $\begin{array}{l}-.036 \\
(.719)\end{array}$ & $\begin{array}{l}.045 \\
(.770)\end{array}$ & $\begin{array}{c}.478 \\
(.000)\end{array}$ & $\begin{array}{l}-.072 \\
(.660)\end{array}$ & & $\begin{array}{l}.030 \\
(.857)\end{array}$ \\
\hline \multirow{3}{*}{ 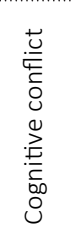 } & q18a & $\begin{array}{l}.258 \\
(.130)\end{array}$ & $\begin{array}{l}.054 \\
(.728)\end{array}$ & $\begin{array}{c}.024 \\
(.873)\end{array}$ & $\begin{array}{l}.306 \\
(.051)\end{array}$ & $\begin{array}{l}.093 \\
(.576)\end{array}$ & & $\begin{array}{l}.141 \\
(.433)\end{array}$ & $\begin{array}{c}.291 \\
(.045)\end{array}$ & $\begin{array}{c}.171 \\
(.383)\end{array}$ & $\begin{array}{l}.288 \\
(.133)\end{array}$ & $\begin{array}{c}.084 \\
(.664)\end{array}$ & 138 & $\begin{array}{c}.306 \\
(.088)\end{array}$ & $\begin{array}{c}.183 \\
(.202)\end{array}$ & $\begin{array}{l}.099 \\
(.592)\end{array}$ & $\begin{array}{c}.348 \\
(.060)\end{array}$ & $\begin{array}{l}.219 \\
(.199)\end{array}$ & $\begin{array}{l}.177 \\
(.199)\end{array}$ & \\
\hline & q18b & $\begin{array}{l}.147 \\
(.356)\end{array}$ & $\begin{array}{l}.257 \\
(.057)\end{array}$ & $\begin{array}{l}.082 \\
(.594)\end{array}$ & $\begin{array}{l}.329 \\
(.043)\end{array}$ & $\begin{array}{c}.188 \\
(.233)\end{array}$ & $\begin{array}{l}.260 \\
(.070)\end{array}$ & $\begin{array}{l}.157 \\
(.396)\end{array}$ & $\begin{array}{l}.376 \\
(.002)\end{array}$ & $\begin{array}{c}.100 \\
(.530)\end{array}$ & $\begin{array}{l}.210 \\
(.131)\end{array}$ & $\begin{array}{l}.141 \\
(.360)\end{array}$ & $\begin{array}{l}.075 \\
(.673)\end{array}$ & $\begin{array}{c}.370 \\
(.003)\end{array}$ & $\begin{array}{c}.345 \\
(.008)\end{array}$ & $\begin{array}{c}.119 \\
(.534)\end{array}$ & $\begin{array}{c}.357 \\
(.016)\end{array}$ & $\begin{array}{c}.313 \\
(.039)\end{array}$ & $\begin{array}{c}.157 \\
(.371)\end{array}$ & \\
\hline & $\mathrm{q} 18 \mathrm{c}$ & $\begin{array}{c}.028 \\
(.833)\end{array}$ & $\begin{array}{l}.121 \\
.(311)\end{array}$ & $\begin{array}{l}-.103 \\
(.443)\end{array}$ & $\begin{array}{l}.105 \\
(.467)\end{array}$ & $(.867)$ & $(.442)$ & (.795) & $(.090)$ & $(.157)$ & $\begin{array}{l}.300 \\
(.008)\end{array}$ & $\begin{array}{l}.377 \\
(.001)\end{array}$ & $(.001)$ & $\begin{array}{l}.344 \\
(.002)\end{array}$ & $\begin{array}{l}.243 \\
(.026)\end{array}$ & $\begin{array}{l}.114 \\
(.473)\end{array}$ & $\begin{array}{c}.354 \\
(.004)\end{array}$ & & $\begin{array}{l}.065 \\
(.641)\end{array}$ & \\
\hline \multirow{5}{*}{ 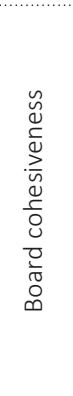 } & q23a & $\begin{array}{c}.086 \\
(.549)\end{array}$ & $\begin{array}{l}.214 \\
(.106)\end{array}$ & $\begin{array}{c}.111 \\
(.434)\end{array}$ & $(.047)$ & $(.535)$ & $(.437)$ & $\begin{array}{l}.131 \\
(.331)\end{array}$ & $\begin{array}{c}.049 \\
(.757)\end{array}$ & $\begin{array}{c}.109 \\
(.429)\end{array}$ & $\begin{array}{l}-.009 \\
(.957)\end{array}$ & $(.084)$ & $(.350)$ & $(.213)$ & $\begin{array}{l}.051 \\
(.606)\end{array}$ & $\begin{array}{c}.123 \\
(.438)\end{array}$ & $\begin{array}{l}.400 \\
(.008)\end{array}$ & $\begin{array}{c}.149 \\
(.340)\end{array}$ & $\begin{array}{l}.103 \\
(.493)\end{array}$ & \\
\hline & $q 23 b$ & $\begin{array}{l}.135 \\
(.336)\end{array}$ & $\begin{array}{l}.080 \\
(.509)\end{array}$ & $\begin{array}{c}.202 \\
(.120)\end{array}$ & $\begin{array}{l}.467 \\
(.000)\end{array}$ & $\begin{array}{c}.183 \\
(.210)\end{array}$ & $\begin{array}{c}.255 \\
(.086)\end{array}$ & $\begin{array}{c}.141 \\
(.383)\end{array}$ & $\begin{array}{l}.196 \\
(.152)\end{array}$ & $\begin{array}{l}-.082 \\
(.610)\end{array}$ & $\begin{array}{c}.196 \\
(.219)\end{array}$ & $\begin{array}{c}.016 \\
(.909)\end{array}$ & $\begin{array}{c}.244 \\
(.102)\end{array}$ & $\begin{array}{c}.332 \\
(.003)\end{array}$ & $\begin{array}{c}.215 \\
(.058)\end{array}$ & $\begin{array}{c}.268 \\
(.063)\end{array}$ & $\begin{array}{c}.483 \\
(.001)\end{array}$ & $\begin{array}{c}.135 \\
(.391)\end{array}$ & $\begin{array}{l}.085 \\
(.533)\end{array}$ & \\
\hline & $\mathrm{q} 23 \mathrm{c}$ & $\begin{array}{l}.262 \\
(.025)\end{array}$ & $\begin{array}{l}.240 \\
(.078)\end{array}$ & $\begin{array}{l}.332 \\
(.026)\end{array}$ & $\begin{array}{c}.222 \\
(.180)\end{array}$ & $\begin{array}{c}.157 \\
(.240)\end{array}$ & $\begin{array}{c}.148 \\
(.378)\end{array}$ & $\begin{array}{l}.480 \\
(.000)\end{array}$ & $\begin{array}{l}.003 \\
(.985)\end{array}$ & $\begin{array}{l}.062 \\
(.619)\end{array}$ & $\begin{array}{l}.077 \\
(.524)\end{array}$ & $\begin{array}{l}.012 \\
(.933)\end{array}$ & $\begin{array}{l}.077 \\
(.673)\end{array}$ & $\begin{array}{l}.265 \\
(.047)\end{array}$ & $\begin{array}{c}.142 \\
(.124)\end{array}$ & $\begin{array}{l}.246 \\
(.120)\end{array}$ & $\begin{array}{c}.394 \\
(.010)\end{array}$ & $\begin{array}{c}.234 \\
(.227)\end{array}$ & $\begin{array}{l}.514 \\
(.002)\end{array}$ & $\begin{array}{l}.329 \\
(.096)\end{array}$ \\
\hline & $q 23 d$ & $\begin{array}{l}.321 \\
(.079)\end{array}$ & $\begin{array}{c}.466 \\
(.004)\end{array}$ & $\begin{array}{l}.294 \\
(.093)\end{array}$ & $\begin{array}{l}.307 \\
(.057)\end{array}$ & $\begin{array}{l}.098 \\
(.581)\end{array}$ & $\begin{array}{c}.334 \\
(.031)\end{array}$ & $\begin{array}{l}.459 \\
(.002)\end{array}$ & $\begin{array}{l}.135 \\
(.341)\end{array}$ & $\begin{array}{c}.446 \\
(.008)\end{array}$ & $\begin{array}{l}.372 \\
(.014)\end{array}$ & $\begin{array}{l}.274 \\
(.067)\end{array}$ & $\begin{array}{c}.216 \\
(.128)\end{array}$ & $\begin{array}{c}.186 \\
(.217)\end{array}$ & $\begin{array}{c}.101 \\
(.261)\end{array}$ & $\begin{array}{l}.118 \\
(.375)\end{array}$ & $\begin{array}{c}.291 \\
(.071)\end{array}$ & $\begin{array}{l}.088 \\
(.703)\end{array}$ & $\begin{array}{l}.260 \\
(.100)\end{array}$ & \\
\hline & q23e & $\begin{array}{c}.101 \\
(.589)\end{array}$ & $\begin{array}{l}.007 \\
(.960)\end{array}$ & $\begin{array}{c}.221 \\
(.166)\end{array}$ & $\begin{array}{l}.138 \\
(.448)\end{array}$ & $\begin{array}{l}.069 \\
(.578)\end{array}$ & $\begin{array}{c}.138 \\
(.323)\end{array}$ & $\begin{array}{l}.384 \\
(.014)\end{array}$ & $\begin{array}{c}.000 \\
(1.00)\end{array}$ & $\begin{array}{l}-.170 \\
(.296)\end{array}$ & $\begin{array}{l}.159 \\
(.436)\end{array}$ & $\begin{array}{l}.105 \\
(.387)\end{array}$ & & $\begin{array}{l}.062 \\
(.717)\end{array}$ & $\begin{array}{l}-.007 \\
(.781)\end{array}$ & $\begin{array}{c}.145 \\
(.348)\end{array}$ & $\begin{array}{l}.105 \\
(.624)\end{array}$ & $\begin{array}{c}.170 \\
(.329)\end{array}$ & $\begin{array}{c}.239 \\
(.288)\end{array}$ & \\
\hline \multirow{4}{*}{ 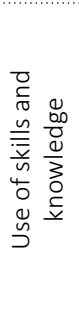 } & q14a & $\begin{array}{c}.056 \\
(.789)\end{array}$ & $\begin{array}{l}.032 \\
(.852)\end{array}$ & $\begin{array}{l}.198 \\
(.231)\end{array}$ & $\begin{array}{c}.202 \\
(.338)\end{array}$ & $\begin{array}{c}.139 \\
(.387)\end{array}$ & $\begin{array}{l}-.008 \\
(.964)\end{array}$ & $\begin{array}{c}.052 \\
(.801)\end{array}$ & $\begin{array}{c}.048 \\
(.792)\end{array}$ & $\begin{array}{l}-.063 \\
(.707)\end{array}$ & $\begin{array}{c}.206 \\
(.206)\end{array}$ & $\begin{array}{c}.083 \\
(.587)\end{array}$ & $\begin{array}{c}.194 \\
(.289)\end{array}$ & $\begin{array}{l}.266 \\
(.077)\end{array}$ & $\begin{array}{c}.044 \\
(.710)\end{array}$ & $\begin{array}{l}-.190 \\
(.338)\end{array}$ & $\begin{array}{c}.230 \\
(.285)\end{array}$ & $\begin{array}{c}.254 \\
(.146)\end{array}$ & $\begin{array}{l}.500 \\
(.011)\end{array}$ & $\begin{array}{l}-.163 \\
(.463)\end{array}$ \\
\hline & $q 14 b$ & $\begin{array}{l}.083 \\
(.643)\end{array}$ & $\begin{array}{l}.214 \\
(.124)\end{array}$ & $\begin{array}{l}.321 \\
(.052)\end{array}$ & $\begin{array}{l}.244 \\
(.109)\end{array}$ & $\begin{array}{c}.238 \\
(.121)\end{array}$ & $\begin{array}{c}.134 \\
(.400)\end{array}$ & $\begin{array}{l}.089 \\
(.641)\end{array}$ & $\begin{array}{l}.039 \\
(.821)\end{array}$ & $\begin{array}{l}.080 \\
(.642)\end{array}$ & $\begin{array}{l}.003 \\
(.983)\end{array}$ & $\begin{array}{l}.060 \\
(.711)\end{array}$ & $\begin{array}{l}.051 \\
(.751)\end{array}$ & $\begin{array}{c}.155 \\
(.187)\end{array}$ & $\begin{array}{c}.223 \\
(.096)\end{array}$ & $\begin{array}{l}.098 \\
(.495)\end{array}$ & $\begin{array}{c}.185 \\
(.194)\end{array}$ & $\begin{array}{l}-.045 \\
(.818)\end{array}$ & $\begin{array}{c}.301 \\
(.054)\end{array}$ & $\begin{array}{l}.161 \\
(.312)\end{array}$ \\
\hline & $\mathrm{q} 14 \mathrm{c}$ & $\begin{array}{l}.517 \\
(.000)\end{array}$ & $\begin{array}{l}.165 \\
(.200)\end{array}$ & $\begin{array}{l}.184 \\
(.101)\end{array}$ & $\begin{array}{l}.419 \\
(.003)\end{array}$ & $\begin{array}{c}.197 \\
(.201)\end{array}$ & $\begin{array}{c}.244 \\
(.062)\end{array}$ & $\begin{array}{l}.349 \\
(.040)\end{array}$ & $\begin{array}{l}.251 \\
(.075)\end{array}$ & $\begin{array}{l}.314 \\
(.069)\end{array}$ & $\begin{array}{l}.470 \\
(.001)\end{array}$ & $\begin{array}{c}.362 \\
(.011)\end{array}$ & $\begin{array}{l}.394 \\
(.004)\end{array}$ & $\begin{array}{c}.457 \\
(.005)\end{array}$ & $\begin{array}{c}.289 \\
(.066)\end{array}$ & $\begin{array}{l}.390 \\
(.010)\end{array}$ & $\begin{array}{c}.625 \\
(.000)\end{array}$ & $\begin{array}{l}.270 \\
(.104)\end{array}$ & $\begin{array}{l}.279 \\
(.078)\end{array}$ & $\begin{array}{l}.394 \\
(.013)\end{array}$ \\
\hline & q14d & $\begin{array}{l}.112 \\
(.444)\end{array}$ & $\begin{array}{l}.128 \\
(.322)\end{array}$ & $\begin{array}{l}-.022 \\
(.879)\end{array}$ & $\begin{array}{l}.265 \\
(.072)\end{array}$ & $\begin{array}{l}.107 \\
(.432)\end{array}$ & $\begin{array}{c}.221 \\
(.087)\end{array}$ & $\begin{array}{l}.158 \\
(.369)\end{array}$ & $\begin{array}{l}.298 \\
(.042)\end{array}$ & $\begin{array}{c}.197 \\
(.242)\end{array}$ & $\begin{array}{l}.325 \\
(.030)\end{array}$ & $\begin{array}{l}.262 \\
(.059)\end{array}$ & $\begin{array}{c}.197 \\
(.183)\end{array}$ & $\begin{array}{l}.314 \\
(.045)\end{array}$ & $\begin{array}{l}.347 \\
(.002)\end{array}$ & $\begin{array}{c}.383 \\
(.008)\end{array}$ & $\begin{array}{l}.352 \\
(.014)\end{array}$ & $\begin{array}{c}.415 \\
(.004)\end{array}$ & $\begin{array}{l}-.109 \\
(.440)\end{array}$ & $\begin{array}{c}.213 \\
(.213)\end{array}$ \\
\hline
\end{tabular}

